\title{
The Political Economy Of American Indian Allotment Revisited
}

\author{
Mathew T. Gregg, Roger Williams University, USA
}

D. Mitchell Cooper, Roger Williams University, USA

\begin{abstract}
This paper criticizes McChesney's (1990) hypothesis that the decisions to initially and subsequently terminate American Indian allotment were based on the Bureau of Indian Affairs' (BIA) interest to inflate their budget. By adopting a richer database on the BIA appropriations from 1877-1945 and correcting for model specification problems, I find no empirical evidence supporting any of McChesney's hypotheses concerning the bureaucratic demand for regulatory change. In fact, other large budgetary items, such as New Deal relief funding, Court of Claims judgments, and educational spending, crowded out BIA land management appropriations over these years. Interestingly, a cursory overview of this period illustrates how the BIA fought for less, rather than more, administrative control over Indian affairs.
\end{abstract}

Keywords: Indian allotment, political economy, crowding out, Bureau of Indian Affairs

\section{INTRODUCTION}

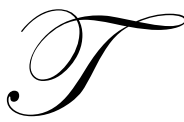

he economics literature concerning the privatization of American Indian lands from 1887-1934 is extremely scarce. This is in stark contrast to the voluminous and detailed narratives written by historians on the allotment and assimilation era (see, for example, Hoxie (1984), Otis (1973), and Prucha (1986)). To date, McChesney (1990) is the only paper to use economic theory, albeit informal, and empirical evidence to explain the government's decision to first adopt and then halt Indian allotment. ${ }^{1}$ McChesney (1990) specifically shows that both pieces of legislation were "complementary parts of an overall political policy that increased bureaucratic budgets while simultaneously serving the aims of well-organized non-Indian interest groups" (299). This paper criticizes McChesney's bureaucratic aggrandizement hypothesis by adopting a richer database on historical BIA appropriations and augmenting McChesney's model specifications albeit slightly. Surprisingly, I find no evidence -- empirical or descriptive -- that the desire or ability to augment the bureau's budget drove Indian policy.

This period in Indian land regulation is important for several reasons. First, while private property rights align private rewards with social benefits, the American Indian experience hardly corroborates with this fundamental economic paradigm. For example, the prima facie evidence of the destructive consequences of allotment on reservations includes the reduction of the Indian land base by roughly 90 million acres from 1887-1934, a decrease in per capita Indian income to roughly one-tenth the US average by 1934, and the impetus of such land ownership problems as checkboarding and fractionalization which still impede optimal land use today. ${ }^{2}$ Second, the perceived failure with privatization propagated the trope that Indian policy recommendations need to provide measures of federal protection against private ownership (Trosper, 1978). Last, prohibiting future allotment and extending the trust period indefinitely over Indian lands intensified federal regulation over Indian affairs that has persisted until the slow transition toward Indian self-determination starting in the 1970s.

\footnotetext{
${ }^{1}$ Carlson $(1981,1983)$ also discusses inter alia the economic reasons for the decline in the relative and absolute level of Indian farming and the positive association between allotting land and farm parity prices. However, an explanation for the passage and, more importantly, the termination of allotment is not undertaken.

${ }^{2}$ Most historians adopt John Collier's claim in 1934 that 96 million acres had been removed from Indian reservations. However, the exact amount of land loss is still somewhat unclear. For example, Collier's estimate of 48 million acres in 1934 under Indian control does not collaborate with a study by the National Resources Board in the same year that calculated the Indian land base at 51.9 million acres.
} 
The general models of regulation are comprised either of market-correcting, public interest or rent-seeking, interest group theories (see, for example, Stigler's (1971) seminal work on capturing rents through regulation). In this particular case, a public interest theory for allotting in severalty hardly seems appropriate two reasons: the lack of evidence of a prevailing market failure and the welfare-diminishing aspects of providing trust patents to Indians with restraints on alienation. ${ }^{3}$ McChesney (1990) finds that only one group -- the BIA -- benefited from initial allotment, the way the government assigned land rights, and the eventual termination of allotment because, in his eyes, each characteristic of the allotment period necessitated greater budgetary appropriations. This explanation fits neatly with Peltzman's (1976) interest group theory of regulation and a tractable empirical counterpart measuring bureaucratic self-interest (see Niskanen 1971).

However, there are several reasons to question this conclusion. First, Casas-Pardo and Puchades-Navarro's (2001) identification of the Niskanen's restrictive assumption of perfect discriminating monopoly power is germane to this period in American Indian history. By the 1930s, the BIA held little bargaining power on budgetary appropriations over the sponsor since bureaucratic X-inefficiency was a chief reason for policy reform. Second, adopting aggregate BIA budget figures generates an identification problem since the effect of changing reservation property rights on the land management portion of the BIA's budget cannot be ferreted out. Finally, while ex post bureaucratic control over tribal land grew after terminating allotment, a closer reading of the primary documents during the 1930s suggests that the ex ante demand to enlarge the BIA's autocratic role in Indian Affairs simply did not exist.

\section{BACKGROUND}

While methods used by the federal government have significantly changed over time, federal Indian policy has been largely driven by the confluence of the ideological demand to "civilize" Indians and the non-Indian demand for Indian resources. Initially, the demand for eastern Indian land led the government to establish a policy to remove Indians west of the Mississippi River during the 1830 s. $^{4}$ Later, when US expansion continued, Indian land cessions during the 1850s contained provisions that established Indians reservations (Prucha, 1986: 108-121). However, when the government liberalized access to the public domain under the Homestead Act of 1862, Congress passed a similar act on Indian reservations in 1887. Amongst competing private interests, eastern religious reform organizations, in particular the religious leaders that attended the influential Lake Mohonk Conferences, were highly influential in pressuring the government to privatize Indian lands. ${ }^{5}$ Their non-pecuniary benefits from advocating privatization aligned, at least initially, with the demand for Indian land by western settlers and railroad companies.

The General Allotment Act of February 8, 1887 or simply the Dawes Act, named after its chief sponsor Senator Henry Dawes, divided reservations into 160-acre parcels for families, 80-acre plots for single men over eighteen, and 40-acre plots to single persons under eighteen (Carlson 1981). An Indian was granted four years after allotment to choose a surveyed plot or the government would provide the assignment for him. The remaining land, termed "surplus" land, was opened for sale and the proceeds were escrowed in the tribe's trust accounts held in the US Treasury. The legal title to allotted land was initially held in trust with the government for a 25-year period in which the land could not be alienated or taxed. In many ways, as Ambler (1990, 10) describes, "Indians received their 'homesteads' generally from communally owned tribal lands; non-Indians received theirs from communally owned public lands."

\footnotetext{
${ }^{3}$ Anderson (1992) provides numerous examples of usufruct property systems among indigenous tribes. Wishart (1996) also estimates that farm self-sufficiency levels among the Cherokees prior to removal were equivalent to their white neighbors. The Cherokees had long held private rights over land improvements -- such as structures, fences and crops -- but not to the land itself. ${ }^{4}$ See Foreman (1932) for a descriptive account of Indian removal specifically pertaining to southeastern tribes.

${ }^{5}$ Senator Dawes told the Lake Mohonk Conference in 1887, "It should be called the Mohonk bill... you are responsible for it" (qtd. in Otis, 1971: 36). Held in upstate New York, politicians like Sen. Dawes, bureaucrats like the Board of Indian Commissioners, and assimilation/religious leaders (e.g., Boston Indian Citizenship Committee, the Indian Rights Association, and the Women's National Indian Association) meet annually from 1883 to 1916 for the weekend to evaluate federal Indian policy. Debates and reports on Indian progress typically dominated the conference (Hoxie, 1984: 12).
} 
Prior to 1903, the government needed tribal consent to allot and sell "surplus" lands on each reservation, which consequentially delayed the opening of land for non-Indians. However, tribal sovereignty was compromised after the passage of Lone Wolf v. Hitchcock in 1903 when the Supreme Court allowed Congress to exercise plenary authority over Indian allotment (Clark 1994). ${ }^{6}$ After 1903, Congress could abrogate prior treaty stipulations and allot reservations without the consent of Indian tribes. Not surprisingly, from 1904-1920, over 15 million acres were allotted whereas roughly 6 million acres were allotted prior to 1904 (Indian Affairs Reports, 1888-1920).

Arguably, the most devastating aspects of allotment acts involved two modifications to the original act. Going against the stated objectives of the Dawes Act, Congress in 1891 overturned a long-standing policy by allowing negotiations for ten-year agricultural and five-year mineral lease contracts (Prucha, 2000: 182-184). ${ }^{7}$ Congressional powers over mineral leasing consequentially expanded in 1909 with the passage of the Indian Appropriations Act, which allowed for allotted land to be "leased for mining purposes for any term of years as may be deemed advisable by the Secretary of the Interior" (Mills and Willingham, 1926: 534). Second, the Burke Act of 1906 liberalized the issuance of fee patents by removing the 25 -year trust period to any Indian declared "competent and capable" (Prucha, 2000: 205-206). Indians containing one-half or less Indian blood were immediately issued fee patents and became US citizens. During the peak of trust-to-fee conversion from 1917-1919, many Indians were forced to receive their titles or were not informed of the removal of federal trust restrictions (Ambler 1990: 14-15). Ironically, Indian Commissioner Francis Leupp in 1908 suggested that lifting restrictions on alienation -- which under standard economic theory would be welfare improving -- should be used as a form of punishment for breaking state laws (Hoxie 1984: 166-167).

After 1920 the general support of allotment by western economic interests and eastern humanitarian groups fell. A deep drop in oil prices caused by overproduction halted oil leasing on Indian lands in 1932. A general downturn in land prices after 1920 also abated the demand for Indian land. A number of humanitarian organizations eventually pledged solidarity to the "Meriam Report," an influential study conducted by the Institute for Government Research (modern-day Brookings Institution) that recommended inter alia ending allotment and halting the bureaucratic oversight in Indian resource management. After 1920 the Secretary of the Interior directed that no Indian should be given a fee patent without thorough investigation. When John Collier, founder of the pro-Indian rights American Indian Defense Association, became Commissioner of Indian Affairs in 1933, his desire to consolidate various federal Indian policy reforms into one bill eventually led to the passage of the Indian Reorganization Act (IRA) on June 18, 1934 that officially ended the policy of allotment (Koppes, 1977).

Besides ending allotment, the IRA extended the trust period indefinitely and authorized an annual appropriation of $\$ 2$ million to increase the size of reservations for landless Indians. Existing "surplus" land was removed from potential sale and returned to the tribe. To stimulate economic recovery, the act established a $\$ 10$ million revolving credit fund available to tribes that established business charters. The IRA also contained a loan program to assist Indian students attending vocational schools. The federal government altered the institutional arrangement of Indian-white relations by guaranteeing the powers of tribal self-government as long as the tribe voted to accept a boilerplate constitution designed by the federal government (Philp 1983). Eventually, 175 tribes accepted the terms of the IRA, whereas 78 reservations including the most-populace tribe, the Navajo, rejected its terms (Reinhardt, 2005).

Given this brief history of the allotment period, McChesney's (1990) results can be discussed in a better light. Along with eastern religious and western economic interests, McChesney (1990) also claims that Congress and the BIA, with their supposed aligned incentives, jointly benefited from initial allotment: "Larger budgets [required from administering privatization] benefited politicians as well since they went for enlargement of the bureaucracy, creating patronage positions of value to politicians" (318). McChesney then explains how restrictions on alienation,

\footnotetext{
${ }^{6}$ The decision was the culmination of government effects to suppress cultural expression on reservations. For example, the Curtis Act of 1898 disbanded tribal courts and stripped tribal governments of its discretionary powers (Amber, 1990).

${ }^{7}$ Prior to 1891, there were no statutes concerning Indian tribal leasing. The Attorney General in 1885 declared all forms of leasing illegal on Indian trust lands. However, in 1891 (26 Stat. 795), allowed mineral and agricultural leasing if an Indian was unable to use the resources "by reason of age or other disability" (FTC, 1975: 11). For an extensive discussion on the history of leasing, in particular with respect to oil and gas, on Indian lands, see McLane (1955).
} 
which were adverse to the interests of non-Indian economic interests, "necessarily increased the amount of work [by the BIA], and hence the budgets, needed to implement the statute" (325). However, these inflated budgets could not persist in the long run, as Congress would become unwilling to appropriate money when interest in allotment declined after 1920. Furthermore, the bureaucratic interest in allotment was expected to decline since the loss of Indian population under the BIA's jurisdiction, caused by issuing fee patents, "diminished the BIA's control over resources" (318). He then adopted the "Meriam" Report's recommendation of "doubling the current appropriations levels" as supportive anecdotal evidence of his budget maximization hypotheses. Therefore, the IRA served, in McChesney's eyes, as a panacea to declining budgets: "Ending allotments and freezing ownership for allotees still under federal trusteeship guaranteed that bureaucratic control would continue" (325).

The chief contribution of McChesney's approach, in my eyes, is its emphasis on the compromises inherent in the various pieces of allotment legislation. After all, while the pure privatization of Indian lands -- a corner solution in a regulator's utility maximization problem -- was in the best interest of non-Indian economic interests, the government placed restraints on alienation and encouraged leasing rather than full-scaled land cessions. This implies that the marginal rate of substitution (of Indian (consumer) surplus for non-Indian (producer) surplus) was strictly positive - i.e., the sponsor placed a positive value on Indian welfare changes. Given these historical events, McChesney develops two testable hypotheses that correspond to his descriptive model: (1.) the passage of the Dawes Act and the IRA should have increased the BIA budget; and (2.) allotments and acreage allotted should have increased the BIA budget but at a decreasing rate. Both hypotheses suggest that allotment had short-run benefits and long-run consequences on the BIA's budget, implying extending the trust period indefinitely ensured bureaucratic power or prestige, both considered correlated with budgets (Niskanen, 1971).

Prior to my empirical reinvestigation, several points of these hypotheses and the adoption of Niskanen's budget maximization model warrant discussion. First, a cursory overview of primary sources written during the 1930s provides no evidence of this supposed ex ante strategy of the BIA to augment Indian private property rights to maximize budgets. For example, John Collier's original draft of the IRA bill required all allotted land to be transferred back to tribal ownership. Ending allotment and turning land management to tribal control was designed to decrease -- and not increase as McChesney claims -- the need for future bureaucratic oversight. In fact, one of the chief recommendations in the "Meriam Report" was "to transfer the administration [of land management issues such as consolidation, heirship problems, and the leasing/selling of lands] to the Indian communities themselves" (U.S. Hearing, 1934: 22). The departmental appropriation increases suggested in the "Meriam Report," which are emphasized by McChesney, were concerned with shifting the nature of Indian education from boarding to day schooling. Thus, the recommendation to expand the budget had nothing in common with changing its land policy.

The eventual enactment that terminated future allotment made land transfers to tribal governments voluntary -- thereby nullifying Collier's objective -- which coincidentally continued the bureaucratic oversight of fractioned allotments. Congress, in particular the co-sponsor Senator Burton Wheeler, pushed for the retention of bureaucratic control in the final act rather than the bureau. Sen. Wheeler's logic was uncompromisingly paternalistic: "in my judgment, if you did it [i.e., turn land management over to tribal control], you would find it would be saturated with all kinds of corruption, and unless it is done by the Department of the Interior, Congress will never appropriate the money" (U.S. House Hearings, 1934: 96-97). Thus, throughout the Congressional hearings on the IRA bill, the bureau pushed to reduce rather than enlarge its autocratic role in land management: "If Congress finds that an Indian tribe can administer a service cheaper and better than the Indian Bureau is doing it, Congress is going to be willing to have the tribe do it (Ibid.). ${ }^{8}$

McChesney's argument concerning ending allotment also hinges on the long run adverse consequences of relaxing the alienation restrictions on the BIA budget. However, the net effect of allotment on the BIA budget is theoretically unclear. I agree that issuing fee patents decreased the Indian land base and the BIA jurisdiction over Indian land management. However, the partial effect of future allotment on the Indian land base would have been

\footnotetext{
${ }^{8}$ The revolving credit fund, which promulgated future bureaucratic oversight, was also added by the House Committee on Indian Affairs and the fund's authorized appropriations increased from an initial request of $\$ 5$ to $\$ 10$ million in the final act. The numerous augmentations of Collier's original draft discarded many of Collier's objectives. See Deloria, Jr. and Lytle (1984: 265270) for a comparison of the two bills.
} 
small since the majority of land loss from allotment occurred from the sale of "surplus" land rather than from liberalizing fee patenting after the Burke Act. By 1934, the demand for potential "surplus" lands would have been muted since roughly $40 \%$ of the existing land base was considered "desert lands or semi-desert, nearly or quite worthless" (Ibid.: 30).

While land under BIA's jurisdiction was falling, the administrating cost of managing un-ceded, allotted land was growing. Problems with fractionalized allotments such as managing leases, selling land, or determining heirs only increased over time. The intensification of fractionalization would have necessitated larger budgets to deal with these non-tangible land management problems. By 1934, the goals of the IRA were not simply to end allotment but to turn "the futile, expensive real-estate transactions [of the BIA] to a minimum" (Ibid.: 711). Thus, $e x$ ante bureaucratic aggrandizement was not the reason for the growth in ex post bureaucratic control after the passage of the IRA. The positive effect of fragmentation from future allotment on the BIA budget could have easily outweighed the negative effect of land loss from fee patenting. In reality, freezing allotment in severalty in 1934 may have decreased the future growth in the BIA budget.

Furthermore, the general theory of regulation as illustrated by Beard et. al. (2003) suggests that standard assumptions of the shape of the sponsor's indifference curves eliminate corner solutions (such as pure privatization and absolute restraints on alienation). While McChesney emphasizes the compromises to various interest groups within the Dawes Act, the same compromises within the IRA are left unmentioned. Given his strong emphasis on the agricultural demand to own Indian land, his "corner solution" interpretation of the IRA (i.e., the interpretation that the IRA solely ended the future alienation of Indian property) eliminates a non-bureaucratic interest group explanation for its passage. While the true intents of the IRA have been mentioned, the omnibus IRA contained numerous compromises that suggest that private interests may have helped maintain this form of regulation over time. ${ }^{9}$

For example, the IRA left open the ability for future allotment even if a tribe did not vote to accept its provisions. Therefore, the sponsor instituted some flexibility to increase future surpluses of non-Indian economic groups. Also, southwestern economic interests succeeded in eliminating the Papago Reservation and its mineral base from the IRA, thereby unaltering the practice of leasing Papago subsurface rights to Arizona mining companies. Finally, the adoption of tribal governments in the IRA, which is considered the most influential component of the IRA, provided a blueprint for the BIA to manage leases for coal, oil, and gas resources on Indian lands. Ambler (2000) finds that these tribal governments, which were all formed from a standardized constitution designed by the BIA, became satellite organizations of the BIA that simply "rubber-stamped" most leasing arrangements. These constitutions maintained that ownership to subsurface and surface rights went to the tribe, thereby ending the complicated split ownership between surface and subsurface rights that existed during the allotment period. Standardizing leasing negotiations would have been in the best interest of mining companies since subsurface rights were initially given to individual allotees, which increased the cost of negotiating large-scale mineral operations.

Lastly, and most importantly, the restrictive assumptions of the Niskanen's (1971) budget maximization model cannot be applied to the relationship between the BIA and the sponsor. In particular, if the BIA's goal was to maximize its budget, then the bureau must maintain perfect bargaining power over the sponsor. This assumption, along with the budget maximization goal, suggests that the bureau oversupplies its "output." Yet, conventional wisdom over the IRA's early years suggests that the sponsor undersupplied its provisions. As Kelly (1975:305-306) clearly writes, "the existing literature on the Collier years... has tended to fix the blame for failure [of the IRA] on a narrow-minded and penny-pinching Congress." One feasible explanation for shortchanging BIA programs is that the appropriations committees, especially during the 1930s, were dominated by western congressmen whose constituents would have borne a disproportionate amount of the costs from the BIA plans to enhance tribal sovereignty. The opposition to appropriation requests only intensified when the BIA acquired a substantial transfer from the New Deal Resettlement Administration to acquire land for Indians (Kelly, 1975).

\footnotetext{
9 By 1940, a Senate bill was drafted to eliminate the provisions of the IRA on reservations focused not on reestablishing allotment but over the agency problems with the newly created tribal councils. An excerpt from these hearings summarizes the concerns of many reservations: "There is less Indian self-government now that ever has been. The attempt to set up a state within a state has failed. Tribes have bound themselves to the Department and councils are following the dictates of the local agencies." (Senate Hearing, 1940: 8-9). The bill eventually died in committee hearings.
} 
Table 1 bears out the lack of bargaining power of the BIA over the sponsor during the 1930 s. ${ }^{10}$ There were four provisions in the IRA that required discretionary approval by the House Committee on the Interior Department Appropriations Bill. The IRA authorized \$250,000 for "defraying the expenses of organizing Indian chartered corporations or other organizations created under this Act," yet Congress never supplied more than $\$ 150,000$ after 1934 (qtd. in Kappler, 1941: 380). The educational loans to reimburse tuition and other expenses in vocational and trade schools were capped at \$250,000 annually, but Congress averaged only $\$ 115,000$ after 1934 . The annual authorized appropriation of \$2 million for land acquisition never exceeded \$1 million during the 1930s and dropped for the remainder of the decade. Most importantly, appropriations to the revolving fund were substantially undercut. The $\$ 10$ million revolving fund was only appropriated $\$ 4.8$ million by 1940 . The fund was eliminated during the war and only revived well after the war. Thus, from 1935 to 1940 , while the IRA authorized a total of $\$ 25$ million in appropriations to the BIA, Congress appropriated just $40 \%$ of this amount.

This evidence suggests that ex ante bureaucratic aggrandizement was not at the heart of private property reforms during the 1930s. Regardless, statistical methods are necessary to disentangle multiple influences on the BIA's budget and validate these anecdotal claims.

Statistical methods can provide evidence of the possible crowding out of the discretionary portions of the BIA budget from increases in funding outside the discretion of the House Committee on Interior Department Appropriations. Fortunately, the availability of historical BIA budgetary data allow for such estimation.

\section{DATA AND EMPIRICAL MODEL}

The BIA budgetary data are collected from two Treasury Department sources: the State of the Finances of the US for the fiscal years 1877-1892, and its predecessor, the Combined Statement of Balances, Appropriations, and Expenditures, for the fiscal years 1893-1945. ${ }^{11}$ Since these documents deduct transfers and repayments to each appropriation type and are written at the end of each fiscal year, they are considered "at present the most comprehensive report[s] of the government's financial operations and the status of appropriations and funds" (Selko, 1940: 521-522). The BIA budget is split into two components: treasury and trust appropriations. Trust accounts contain payments to tribes from past treaty stipulations, royalties from selling and leasing allotted lands, and interest on investments held by the federal government under the name of a tribe. The treasury appropriations contain funding for BIA salaries, education, health, irrigation, land management, Court of Claims judgments, and, during the 1930s, New Deal relief transfers from independent offices to the BIA.

The appropriation figures contained in the Annual Reports of the Commissioner of Indian Affairs (see Fig. 1) are not adopted for four simple reasons. First, the Annual Reports data are incomplete since the appropriations from 1915 to 1919 and 1941 to 1945 are missing. The annual report data also understates both the mean and variance of actual BIA end-of-the-year appropriations. Second, data in the Annual Reports are highly aggregated; only during the $1930 \mathrm{~s}$ is the budget disaggregated into components such as trust, education, and irrigation accounts. Third, the annual report data contain measurement error. For example, the 1934 appropriations figure in the Annual Report refers to the BIA's allocation in the annual Interior Department Appropriations Act for that year, which excludes the supplementary appropriations from deficiency acts, private relief acts, and emergency relief acts. Fourth, and most importantly, transfers to the BIA during the New Deal, which amounted to \$56 million from 1933 to 1939 , were omitted from the Annual Report figures. The Treasury documents allow for a continuous time series on BIA budgets, the disaggregation of the total budget, and complete, year-end BIA appropriations.

\footnotetext{
10 The 1936 Interior Department Appropriations Act, which contained the initial IRA appropriations, was made immediately available in FY 1935. The appropriations in the next year were not made immediately available, expect for the educational appropriations, and thus the majority of IRA appropriations contained in the 1937 Interior Department Appropriations Act were not placed on the government's books until 1938 (Digest of Appropriations, 1936-1938).

${ }^{11}$ Section 15 of the Act of July 31, 1894 required the Secretary of the Treasury to provide "an accurate statement of receipts and expenditures... by each separate head of appropriation" (qtd. in Payne and Banning, 1940: 44).
} 
McChesney's empirical models are as follows:

$$
\begin{aligned}
& \text { BUDGET }_{\mathrm{t}}=\beta_{0}+\beta_{1} * \text { DAWES }+\beta_{2} * \text { IRA }+\beta_{3}{ }^{*} \mathrm{Z}_{\mathrm{t}}+\varepsilon \\
& \text { BUDGET }_{\mathrm{t}}=\beta_{0}+\beta_{1} * \text { Allotments }_{\mathrm{t}}+\beta_{2} * \text { Allotments }^{2}{ }_{\mathrm{t}}+\beta_{3}{ }^{*} \mathrm{z}_{\mathrm{t}}+\varepsilon_{\mathrm{t}} \\
& \text { BUDGET }_{\mathrm{t}}=\beta_{0}+\beta_{1} * \text { Acreage }_{\mathrm{t}}+\beta_{2} * \text { Acreage }^{2}{ }_{\mathrm{t}}+\beta_{3}{ }^{*} \mathrm{z}_{\mathrm{t}}+\varepsilon_{\mathrm{t}}
\end{aligned}
$$

where BUDGET $_{\mathrm{t}}$ is the BIA total appropriations in year $\mathrm{t}$, DAWES represents 1 for 1888 on, 0 otherwise, IRA is 1 for 1935 on, 0 otherwise, the allotment variable shows the number of allotments approved, the acreage variable is the number of acres allotted in a particular year, and $z$ represents a vector of covariates including Indian population and general trends in U.S. economic activity. ${ }^{12}$

There are three general econometric issues with these model specifications. First, an examination of the raw data in Fig. 1 reveals a potential problem with this method. Specially, nominal BIA appropriations appear nonstationary; i.e., its mean and variance are not constant over time. This suggests that omitting a time trend (or not differencing the data) could lead to spurious results. Second, eqs. (2) and (3) do not directly address McChesney's claim that over time allotting land would lower the budget. Interacting allotments and allotted acreage with time dummies will directly test this hypothesis. Third, the general increase in the BIA budget may be a function of the increases to the relief or educational components of their BIA budget, rather than land management budgetary items. These data allow for such disaggregation and thus, budgetary trends concerning the management of Indian land can be better isolated.

\section{RESULTS}

Various regressions, modeled after Eqs. (1)-(3), are estimated using the Cochrane-Orcutt procedure to account for first-order serial correlation and the results of these regressions are shown in Table. $2 .{ }^{13}$ Column 1 presents the unconditional results of Eq. (1). The results suggest that the passage of the Dawes Act and the IRA were not associated with higher appropriations; in fact, the IRA dummy variable is negative and statistically significant once a time trend is included. In particular, the passage of the IRA was roughly associated with a 33\% decrease in the growth rate of BIA appropriations. By adding two lagged variables for Indian population (which is unavailable from 1941 to 1945) and nominal GDP to this model, the results in Column 2 also suggest that neither act increased the growth rate in the BIA budget. The statistical significance of the IRA variable is reduced due to the high correlation with Indian population variable and the reduction in the sample size. Though not shown, the negative and significant coefficient on the IRA dummy variable is reestablished when lagged Indian population is excluded. ${ }^{14}$

Columns 3-6 of Table 2 present various models that determine if the number of allotments and acreage allotted added decreasing amounts to the overall budget. Columns 3 and 4 suggest the number of allotments did not have a diminishing effect on the BIA budget; rather, there is evidence, albeit imprecise, that allotments progressively added more to the BIA budget. Columns 5 and 6 suggest that same imprecise relationship with respect to acres allotted. Though not shown, two simple regression models of logged BIA funds on logged allotments and on logged allotted acres generate small and negative partial effects, however these coefficients are only significant at the $12 \%$ and $16 \%$ levels respectively. Thus, there is no definite empirical evidence that allotment was in the best interest of a budget-oriented bureaucracy.

\footnotetext{
${ }^{12}$ The number of allotments, allotted acreage, and Indian population are collected from the Annual Reports of the Commissioner of Indian Affairs. The data on nominal GDP are obtained from the Historical Statistics, Millennium Edition.

${ }^{13}$ Adding a time trend ensures that logged BIA appropriations are (trend) stationary. Using the AIC criteria to determine the lag order, an augmented Dickey Fuller (ADF) equation of $\Delta \ln \mathrm{Y}_{\mathrm{t}}=\alpha_{0}+\alpha_{1} \ln \mathrm{Y}_{\mathrm{t}-1}+\alpha_{2} \mathrm{~T}+\sum_{\mathrm{i}} \alpha_{\mathrm{i}} \Delta \ln \mathrm{Y}_{\mathrm{t}-\mathrm{i}}+\varepsilon$ yields a test statistic of -5.646 with a p-value of 0.000 . The ADF test statistics on BIA budgets (in levels) with and without a time trend are -2.967 , and -1.053 , respectively. Both tests suggest that the null hypothesis of $\alpha_{1}=0$ cannot be rejected when BIA appropriations are in levels.

${ }^{14}$ These results are available from the author. The negative and insignificant partial effects are also robust when squaring the time trend to allow for a non-linear growth rate and when converting the budget into real terms.
} 
These results are tested for robustness by isolating only the land management portions of the BIA budget. Education appropriations, New Deal relief funds, and Court of Claims judgments are thereby excluded from the total budget variable and each model in estimated. The land management variable is thus compromised of funds for salaries and general expenses, general administration, health, fulfilling treaty stipulations, irrigation, land purchases, industrial assistance, and trust accounts. The results are shown in Table 3. Columns 1 and 2 illustrate the same results as the earlier unadjusted regression models. Passage of the IRA reflects a $37 \%$ decrease in the growth rate in land management appropriations. Columns 3-6 contain the same results as earlier: the first- and second-order terms on allotments and acreage allotted are all insignificant. Again, the most plausible explanation for these results is that the decline in the number of acres under BIA jurisdiction -- which would have decreased the demand for BIA land management funds -- was offset by the growth in its role in managing heirship problems -- which necessitated greater budgetary demands. ${ }^{15}$

Interacting time dummies with the number of allotments and acres allotted further tests the robustness of these results. Using a dummy variable isolating the years after 1920, a Cochrane-Orcutt regression of logged land management appropriations on a time trend, logged allotments, an interaction term, lagged logged Indian population, and lagged logged nominal GDP yields an elasticity of land management appropriations with respect to allotments that is negative and insignificant ( -0.063 with a $\mathrm{p}$-value of 0.112$)$ and an interaction term that is positive but insignificant (-0.234 with a p-value of 0.345). This provides evidence, albeit imprecise, that the structural break in the partial effects of allotment on the BIA budget worked in the opposite direction as claimed by McChesney. The same general results hold for acreage allotted: the coefficient on logged acres is negative but insignificant and the coefficient on the interaction term is positive and highly insignificant.

In sum, these results suggest that there is no empirical evidence that the IRA and Dawes Act dramatically altered the BIA's budget. Isolating the land management appropriations only collaborates with earlier results. In fact, under certain model specifications, there is statistical significant evidence that passing of the IRA decreased the growth rate in the BIA budget. Regardless of the model specification, there is also no evidence of a diminishing role of allotment on either the total budget or the land management portion of the BIA's budget. One possible hypothesis for the lack of statistically significant relationships between the land management policy reforms and the BIA budget is that the discretionary components of BIA land management funding were constrained by changes in other portions of the BIA budget that were either large but unrelated to land reforms, such as educational appropriations, or increases in the budget from sources outside the sponsor's appropriations committees such as New Deal emergency funds or Court of Claims judgment appropriations. Unlike the passage of these enactments, Congressional appropriations members, especially western congressmen, could "vote" in their constituents' interests by underfunding certain aspects of the BIA budget, particularly the projects that imposed the highest costs on their respective special interest groups. Certain components of the land management budget such as the expansion of the Indian land base, land used or held by whites, would have done exactly that.

To determine if funding from other sources crowded out discretionary funds for land management, the land management appropriations are tested in a pairwise fashion with three types of BIA funds to determine if they are cointegrated. First, New Deal funds were mostly transferred to the BIA through the assistance of the Secretary of the Interior Harold Ickes, a pro-Indian reformist who himself once was considered to head the BIA. Second, the Court of Claims judgments reflect large increases in the BIA and were appropriated by the decisions from the Court of Claims. Typically, claims were against the poor management of the BIA budget. Favorable decisions would have possibly decreased the bargaining power of the BIA to further enhance its budget. Third, educational appropriations represent a large portion of the budget and grew substantially after 1930 as there was a regime change from boarding to day school education. A budget-conscious Congress may have been willing to fund the educational process that provides fewer direct costs to their special interests, but these budgetary approvals to Indian education may have hinder the total growth in other parts of the BIA budget. For these results, these variables are chosen to test this crowding out hypothesis.

\footnotetext{
15 Though the results are not shown, each model in Table 3 is also calculated in real terms. The Dawes dummy variable does become positive but highly insignificant. The IRA variable is negative and insignificant under various model specifications. The signs and significance are identical for the allotments and acres variables in Table 3.
} 
In order to use cointegration tests, first the variables need to be non-stationary and integrated of the same order. The results from various augmented Dickey Fuller tests are shown in Table 4. All the variables are nonstationary and integrated of the same order. Second, to determine if any cointegrating relationships hold, I apply Johansen's $(1991,1995)$ maximum likelihood cointegration tests. The results are shown in Table 5. These results reveal there is a cointegrating relationship with all the appropriation types. Both test statistics confirm this. Column 5 of Table 5 shows that higher levels of education, relief, and judgment appropriations are associated with lower levels of land funding. This relationship is stronger with education and judgment appropriations.

The last step to determine the crowding out effect is to infer causality, which is employed using Granger (1969) causality tests. This test is employed for each pair of statistically significant cointegrating relationships. As shown in Table 6, changes in education and relief funds cause changes to land funding. The causality tests thereby suggest that causality flows from relief and education funding to the land-oriented budget. No causality relationship can be determined between land management and judgment funding. Regardless, in combination with the results in Table 5, this analysis provides some insight in the absence of budgetary enhancements from initiating and then stopping allotment. These tests suggest that the growth in the relief and education portions of the BIA budget crowded out growth in land management appropriations.

\section{CONCLUDING REMARKS}

In sum, this paper concludes that ignoring an upward trending BIA budget yields spurious relationships in support of a bureaucratic aggrandizement hypothesis. The growth in this BIA budget identified by McChesney (1990) from changing its private property regimes is simply accidental. Adopting a time trend and isolating changes in the land management portion of the budget produce no evidence, and sometimes contradictory, of budgetary growth from the passage of Indian land reforms. These findings collaborate with anecdotal evidence on the expressed intentions of the IRA's original draft and the conflicting nature of allotment on the BIA's budget. Furthermore, the limited bureaucratic bargaining power over its discretionary funds concerning land management is both gleaned from primary sources and supported with econometric rigor.

If BIA aggrandizement cannot explain the decision to alter federal Indian policy in 1887 and 1934 respectively, then is there any alternative interest group explanation for regulatory change? Banner (2005: 335fn62) has also challenged the BIA aggrandizement hypothesis by suggesting that "the rise and fall of eastern white humanitarian support for allotment better explains events, in my view, than the effects of allotment and its subsequent abolition on the BIA's budget." Universal support against allotment by reform groups was actually slower than Banner's conjecture. Even by 1930, there was still a surprising modicum of support for allotment by Christian organizations like the prominent Indian Rights Association who was hardly supportive of Collier's original bill (Blend, 1983). For example, in their 1934 Annual Report, support for the passage of IRA was subdued: "Many features of the Act are good; it is much better than the original bill but it contains some doubtful features that certainly will need revision" (Annual Report, 1934: 12). Daily (2004: 80-99) also documents the continued support of allotment by various influential humanitarian interests such as the Home Mission Council of the Federal Council of Churches, the Christian Reformed Church, and certain members of the Board of Indian Commissioners during the Wheeler-Howard Act Congressional hearings in 1934.

The development of a unified theory of Indian policy will most likely rule out any private interest approach. Otis (1973) aptly surveyed the historical literature on Indian allotment to rule out any rent-seeking behavior by western settlers, ranchers and railroads in the development the BIA's land policy. Most historians believe that allotment was a mistake, remedied with the passage of the IRA. This simple explanation may have some merit. The privatization of land was coupled with the disbandment of tribal governments, a public good on all reservations. Years of costly and ineffective BIA land management may reflect an unfortunate but necessary cost of having a paternalistic sovereign finance tribal governments. As mentioned above, if the federal government was unwilling to appropriate funding for tribal-led land management practices, then the costs of the federal trust relationship needs to be compared to the benefit of establishing federally-recognized tribal governments. This conjecture suggests that a second-best theory of ending the privatization of reservations may be surprisingly germane to the American Indian experience. 


\section{AUTHOR INFORMATION}

Matthew Gregg is an Assistant Professor of Economics in the Gabelli School of Business at Roger Williams University. D. Mitchell Cooper is a former student at Roger Williams University.

\section{REFERENCES}

1. Ambler, Marjane. Breaking the Iron Bonds: Indian Control of Energy Development. Lawrence, KS: University Press of Kansas, 2000.

2. Anderson, Terry L. (ed.). Property Rights and Indian Economies. Lantham, Md.: Rowman and Littlefield, 1992.

3. Annual Report of the Board of Directors of the Indian Rights Association for the two years ending December 15, 1934. Philadelphia, PA, 1935.

4. Banner, Stuart. How the Indians Lost Their Land. Cambridge: The Belknap Press of Harvard University Press, 2005.

5. Beard, T. Randloph, David L. Kaserman, and John W. Mayo. "A Graphical Exposition of the Economic Theory of Regulation." Economic Inquiry 41, no. 4 (2003): 592-606.

6. Blend, Benay. "The Indian Rights Association, the Allotment Policy, and the Five Civilized Tribes, 19231936." American Indian Quarterly 7, no. 2 (1983): 67-80.

7. $\quad$ Carlson, Leonard A. "Land Allotment and the Decline of American Indian Farming." Explorations in Economic History 18 (1981): 128-154.

8. Carlson, Leonard A. "Federal Policy and Indian Land: Economic Interests and the Sale of Indian Allotments, 1900-1934." Agricultural History 57, no. 1 (1983): 33-45.

9. C Casas-Pardo, Jose, and Miguel Puchades-Navarro. "A Critical Comment on Niskanen's Model." Public Choice 107 (2001): 147-167.

10. Clark, Blue. Lone Wolf v. Hitchcock: Treaty Rights and Indian Law at the End of the Twentieth Century. Lincoln: University of Nebraska Press, 1994.

11. Daily, David W. Battle fore the BIA: G.E.E. Lindquiest and the Missionary Crusade against John Collier. Tuscon: The University of Arizona Press, 2004.

12. Deloria, Jr., Vine, and Clifford M. Lytle. The Nations Within: The Past and Future of American Indian Sovereignty. Austin: University of Texas Press, 1984.

13. Getches, David H., Daniel M. Rosenfelt, and Charles F. Wilkinson, eds. Federal Indian Law Cases and Materials. St Paul, Minn.: West Publishing Co., 1979.

14. Granger, Clive. "Investigating Causal Relations by Econometric Models and Cross-Spectral Models." Econometrica 37 (1969): 424-438.

15. Hoxie, Frederick E. A Final Promise: The Campaign to Assimilate the Indians, 1880-1920. Lincoln: University of Nebraska Press, 1984.

16. Johansen, Søren. "Estimation and Hypothesis Testing of Cointegration Vectors in Gaussian Vector Autoregressive Models." Econometrica 59 (1991): 1551-80.

17. Johansen, Søren. Likelihood-based Inference in Cointegrated Vector Autoregressive Models. Oxford: Oxford University Press, 1995.

18. Kappler, Charles J. (ed.). Indian Affairs: Laws and Treaties. Vol. 5, Laws. Washington, D.C.: GPO, 1941.

19. Koppes, Clayton R. "From New Deal to Termination: Liberalism and Indian Policy, 1933-1953." The Pacific Historical Review 46, no. 4 (1977): 543-566.

20. McChesney, Fred S. "Government as Definer of Property Rights: Indian Lands, Ethnic Externalities, and Bureaucratic Budgets." The Journal of Legal Studies 19, no. 2 (June 1990): 297-335.

21. McLane, Alfred E. Oil and Gas Leasing on Indian Lands. Albany, N.Y.: M.T. Bender Co., 1955.

22. Niskanen, William A. Bureaucracy and Representative Government. Chicago: Aldine Atherton, 1971.

23. Otis, D.S. The Dawes Act and the Allotment of Indian lands. Norman, OK: University of Oklahoma Press, 1973.

24. Payne, John B., and Paul D. Banning. "Federal Accountkeeping." The Accounting Review 15, no. 1 (1940): 31-52.

25. Peltzman, Sam. "Towards a More General Theory of Regulation." Journal of Law and Economics 19, no. 2 (1976): 211-240. 
26. Philp, Kenneth R. "Termination: A Legacy of the Indian New Deal." The Western Historical Quarterly 14, no. 2 (1983): 165-180.

27. Prucha, Francis Paul. The Great Father: The United States Government and the American Indians. Abridged. Lincoln: University of Nebraska Press, 1986.

28. Prucha, Francis Paul (ed.). Documents of United States Indian Policy. Lincoln: University of Nebraska Press, 2000.

29. Reinhardt, Akim D. "A Crude Replacement: The Indian New Deal, Indirect Colonialism, and Pine Ridge Reservation." Journal of Colonialism and Colonial History 6, no. 1 (2005): 1-56.

30. Rusco, Elmer R. A Fateful Time: The Background and Legislative History of the Indian Organization Act. Reno, Nev.: University of Nevada Press, 2000.

31. Selko, Daniel T. The Federal Financial System. Washington, D.C.: The Brookings Institution, 1940.

32. Stigler, George J. "The Theory of Economic Regulation." The Bell Journal of Economics and Management 2, no. 1 (1971): 3-21.

33. Trosper, Ronald L. "American Indian Relative Ranching Efficiency." The American Economic Review 68, no. 4 (1978): 503-516.

34. U.S. Congress, House. Committee on Indian Affairs. Hearings on H.R. 7902 before the House of Representatives' Committee on Indian Affairs. 75th Cong., 2d sess. Washington, D.C.: GPO, 1934.

35. U.S. Congress, Senate. Committee on Indian Affairs. Repealing the So-Called Wheeler-Howard Act. 78th Cong., 2d sess. Washington, D.C.: GPO, 1944.

36. U.S. Department of the Interior, Office of Indian Affairs. Annual Reports of the Commissioner of Indian Affairs to the Secretary of Interior. Washington D.C.: GPO, 1877-1945.

37. U.S. Department of the Interior, Federal Trade Commission. Staff Report on Mineral Leasing on Indian Lands. Washington D.C.: GPO, 1975.

38. U.S. Treasury Department, Bureau of Accounts. State of the Finances of the US. Washington D.C.: GPO, 1877-1892.

39. U.S. Treasury Department, Bureau of Accounts. Combined Statement of Balances, Appropriations, and Expenditures. Washington, D.C.: GPO, 1893-1945.

40. U.S. Treasury Department, Division of Bookkeeping and Warrants. Digest of Appropriations for the Support of the Government of the United States. Washington, D.C.: GPO, 1936-1938.

41. Wishart, David M. "Evidence of Surplus Production in the Cherokee Nation Prior to Removal." The Journal of Economic History 55, no. 1 (1995): 120-138. 
Figure 1: Indian Bureau Regular, Tribal and Special Funds, 1877-1945

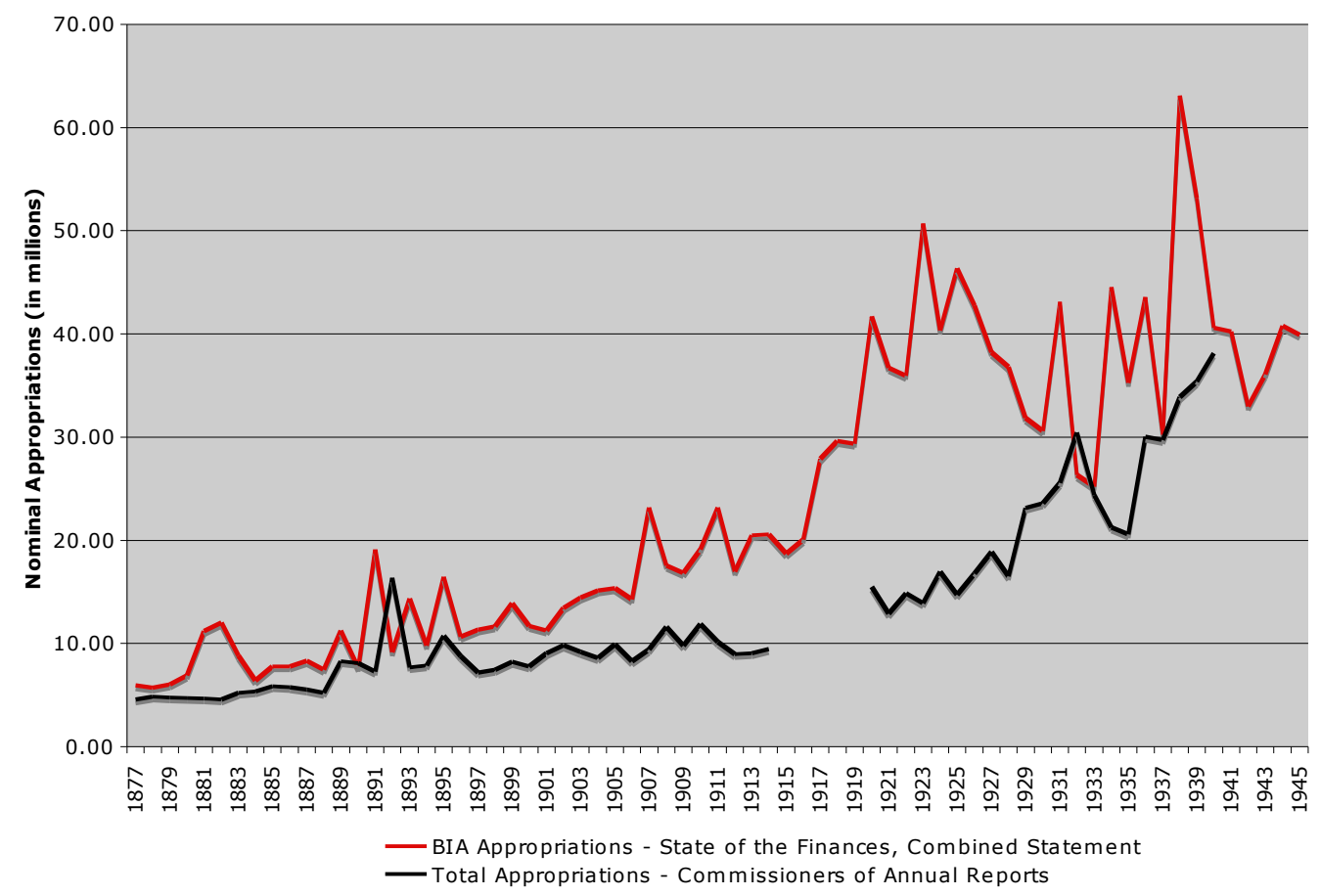

Source: The State of the Finances of the US for the fiscal years 1877-1892, and the Combined Statement of Balances, Appropriations, and Expenditures for the fiscal years 1893-1945. The Annual Report of the Commissioner of Indian Affairs, 1877-1914, 1920-1940.

Table 1: Indian Reorganization Act Appropriations, 1935-1940 (Fraction of Total Annual Authorization in Parentheses)

\begin{tabular}{|c|c|c|c|c|c|c|}
\hline Variable & 1935 & 1936 & 1937 & 1938 & 1939 & 1940 \\
\hline Organizing Indian Corporations & $\begin{array}{l}\$ 150 \\
(0.60)\end{array}$ & $\begin{array}{c}\$ 0 \\
(0.00)\end{array}$ & $\begin{array}{c}\$ 0 \\
(0.64)\end{array}$ & $\begin{array}{l}\$ 130 \\
(0.52)\end{array}$ & $\begin{array}{c}\$ 80 \\
(0.32)\end{array}$ & $\begin{array}{c}\$ 80 \\
(0.32)\end{array}$ \\
\hline Acquisition of Indian Lands & $\begin{array}{c}\$ 1,000 \\
(0.50)\end{array}$ & $\begin{array}{c}\$ 0 \\
(0.00)\end{array}$ & $\begin{array}{c}\$ 1,000 \\
(0.50)\end{array}$ & $\begin{array}{l}\$ 950 \\
(0.48)\end{array}$ & $\begin{array}{l}\$ 500 \\
(0.25)\end{array}$ & $\begin{array}{c}\$ 650 \\
(0.33)\end{array}$ \\
\hline Revolving Fund & $\begin{array}{c}\$ 2,500 \\
(0.25)\end{array}$ & $\begin{array}{c}\$ 0 \\
(0.00)\end{array}$ & $\begin{array}{c}\$ 980 \\
(0.10)\end{array}$ & $\begin{array}{l}\$ 520 \\
(0.05)\end{array}$ & $\begin{array}{c}\$ 400 \\
(0.04)\end{array}$ & $\begin{array}{c}\$ 400 \\
(0.04)\end{array}$ \\
\hline Educational Funds & $\begin{array}{c}\$ 0 \\
(0.00)\end{array}$ & $\begin{array}{c}\$ 175 \\
(0.70)\end{array}$ & $\begin{array}{c}\$ 0 \\
(0.00)\end{array}$ & $\begin{array}{c}\$ 50 \\
(0.20)\end{array}$ & $\begin{array}{l}\$ 100 \\
(0.40)\end{array}$ & $\begin{array}{l}\$ 135 \\
(0.54)\end{array}$ \\
\hline Total IRA Funding & $\begin{array}{c}\$ 3,650 \\
(0.29)\end{array}$ & $\begin{array}{l}\$ 175 \\
(0.01)\end{array}$ & $\begin{array}{c}\$ 2,140 \\
(0.17)\end{array}$ & $\begin{array}{c}\$ 1,650 \\
(0.13)\end{array}$ & $\begin{array}{c}\$ 1,080 \\
(0.09)\end{array}$ & $\begin{array}{l}\$ 1,265 \\
(0.10)\end{array}$ \\
\hline
\end{tabular}

Notes: The appropriations are expressed in thousands ( $\$ 000 \mathrm{~s})$. For "organizing Indian corporations" and "for loans to Indians for vocational and trade schools," the BIA was authorized to spend $\$ 250,000$ annually on each program. For the "acquisition of Indian lands," the IRA authorized \$2 million annually. For "loans to tribal corporations for economic development," Congress authorized an appropriation of $\$ 10$ million.

Source: Combined Statement of Balances, Appropriations, and Expenditures, 1935-1940. 
Table 2: GLS Estimates of the Bureaucratic Aggrandizment Hypothesis (t-Statistics in Parenthesis)

\begin{tabular}{|c|c|c|c|c|c|c|}
\hline Variable & Model 1 & Model 2 & Model 3 & Model 4 & Model 5 & Model 6 \\
\hline trend & $\begin{array}{l}0.0394 * * * \\
(9.34)\end{array}$ & $\begin{array}{l}0.0219 * \\
(1.80)\end{array}$ & $\begin{array}{l}681595.0 * * * \\
(9.67)\end{array}$ & $\begin{array}{l}523090.5 * * * \\
(3.72)\end{array}$ & $\begin{array}{l}692224.4 * * * \\
(9.66)\end{array}$ & $\begin{array}{l}502860.0 * * * \\
(3.50)\end{array}$ \\
\hline Dawes (year=1888) & $\begin{array}{l}-0.205 \\
(-1.13)\end{array}$ & $\begin{array}{l}-0.157 \\
(-0.58)\end{array}$ & & & & \\
\hline IRA (year=1935) & $\begin{array}{l}-0.356^{* *} \\
(-2.01)\end{array}$ & $\begin{array}{l}-0.055 \\
(-0.28)\end{array}$ & & & & \\
\hline $\ln (\text { Pop })_{t-1}$ & & $\begin{array}{l}-0.472 \\
(-0.06)\end{array}$ & & & & \\
\hline $\ln (G D P)_{t-1}$ & & $\begin{array}{l}0.387 \\
(1.47)\end{array}$ & & & & \\
\hline Allotments $_{\mathrm{t}}$ & & & $\begin{array}{l}-856.2 \\
(-0.89)\end{array}$ & $\begin{array}{l}-956.7 \\
(-0.90)\end{array}$ & & \\
\hline Sq. Allotments ${ }_{t}$ & & & $\begin{array}{l}0.0507 \\
(0.56)\end{array}$ & $\begin{array}{l}0.0593 \\
(0.62)\end{array}$ & & \\
\hline Acres $_{\mathrm{t}}$ & & & & & $\begin{array}{l}-2.169 \\
(-0.50)\end{array}$ & $\begin{array}{l}-3.437 \\
(-0.78)\end{array}$ \\
\hline Sq. Acres ${ }_{t}$ & & & & & $\begin{array}{l}0.000000934 \\
(0.48)\end{array}$ & $\begin{array}{l}0.00000141 \\
(0.70)\end{array}$ \\
\hline Pop $_{t-1}$ & & & & $\begin{array}{l}21.39 \\
(0.49)\end{array}$ & & $\begin{array}{l}23.94 \\
(0.54)\end{array}$ \\
\hline $\mathrm{GDP}_{\mathrm{t}-1}$ & & & & $\begin{array}{l}126.17 \\
(1.36)\end{array}$ & & $\begin{array}{l}141.63 \\
(1.49) \\
\end{array}$ \\
\hline $\mathrm{N}$ & 68 & 63 & 68 & 63 & 68 & 63 \\
\hline Adj $R^{2}$ & 0.712 & 0.789 & 0.598 & 0.739 & 0.580 & 0.731 \\
\hline $\mathrm{F}$ & $56.09 * * *$ & $42.70 * * *$ & $34.17 * * *$ & $36.14 * * *$ & $31.79 * * *$ & $34.65 * * *$ \\
\hline DW Stat & 1.92 & 1.94 & 2.12 & 1.99 & 2.14 & 2.00 \\
\hline
\end{tabular}

Notes: * Denotes significance at the 0.10 level, $* *$ at the 0.05 level, and *** at the 0.01 level.

Standard errors are corrected for first-order serial correlation using the Cochrane-Orcutt procedure. The coefficient and standard errors of the constant term are omitted from this table.

Source: See text. 
Table 3:GLS Estimates of Land Management Appropriations (t-Statistics in Parenthesis)

\begin{tabular}{lll}
\hline \hline Variable & Model 1 & Model 2 \\
\hline trend & $\begin{array}{l}0.039 * * * \\
(9.36)\end{array}$ & $\begin{array}{l}0.0226 * \\
(1.90)\end{array}$ \\
& & \\
Dawes (year=1888) & -0.228 & -0.191 \\
& $(-1.26)$ & $(-0.72)$ \\
& & \\
IRA (year=1935) & $-0.379 * *$ & -0.077 \\
& $(2.14)$ & $(-0.40)$ \\
& & -0.055 \\
$\ln ($ Pop) & & $(-0.07)$ \\
& & \\
$\ln (\mathrm{GDP})_{\mathrm{t}-1}$ & & 0.381 \\
& & $(1.34)$
\end{tabular}

\begin{tabular}{|c|c|c|}
\hline Allotments $_{\mathrm{t}}$ & $\begin{array}{l}-753.79 \\
(-0.84)\end{array}$ & $\begin{array}{l}-980.24 \\
(-0.98)\end{array}$ \\
\hline Sq. Allotments ${ }_{t}$ & $\begin{array}{l}0.039 \\
(-0.48)\end{array}$ & $\begin{array}{l}0.049 \\
(-0.57)\end{array}$ \\
\hline
\end{tabular}

Acres $_{\mathrm{t}}$ 
Table 4: Augmented Dickey Fuller Test Results (p-Values in Parentheses)

\begin{tabular}{|c|c|c|c|c|}
\hline Variable & Lag Order & $\begin{array}{c}\mathrm{H}_{0}: \text { Not Stationary in } \\
\text { Levels }\end{array}$ & $\begin{array}{c}\mathrm{H}_{0}: \text { Not Trend } \\
\text { Stationary }\end{array}$ & $\begin{array}{c}\mathrm{H}_{\mathbf{0}}: \text { Not Difference } \\
\text { Stationary }\end{array}$ \\
\hline Education & 4 & $\begin{array}{l}-0.284 \\
(0.927)\end{array}$ & $\begin{array}{l}-1.927 \\
(0.641)\end{array}$ & $\begin{array}{c}-4.452 * * * \\
(0.002)\end{array}$ \\
\hline Emergency Relief & 3 & $\begin{array}{l}-2.405 \\
(0.140)\end{array}$ & $\begin{array}{l}-2.787 \\
(0.202)\end{array}$ & $\begin{array}{c}-4.540 * * * \\
(0.002)\end{array}$ \\
\hline Land & 3 & $\begin{array}{l}-0.928 \\
(0.778)\end{array}$ & $\begin{array}{l}-2.387 \\
(0.386)\end{array}$ & $\begin{array}{l}-4.538 * * * \\
(0.001)\end{array}$ \\
\hline Judgments & 3 & $\begin{array}{c}1.481 \\
(0.997) \\
\end{array}$ & $\begin{array}{l}-0.289 \\
(0.989) \\
\end{array}$ & $\begin{array}{c}-3.259 * * \\
(0.016)\end{array}$ \\
\hline
\end{tabular}

Notes: The lag order was determined using the AIC criteria. $* *$ denotes significance at the 0.05 level, $* * *$ denotes significance at the 0.01 level.

Source: See text.

Table 5: Johansen Cointegration Test Results and Cointegrating Relationships

\begin{tabular}{|c|c|c|c|c|c|}
\hline Variable & Lag Order & Hypothesis & Trace Statistic & $\begin{array}{c}\text { Max. } \lambda \\
\text { Statistic }\end{array}$ & $\begin{array}{c}\text { Cointegrating } \\
\text { Coefficient } \\
\text { (Standardized) }\end{array}$ \\
\hline Education/Land & 1 & $\mathrm{H}_{0}: \mathrm{r}=0 \mathrm{H}_{1}: \mathrm{r}>=1$ & $20.859 * * *$ & $19.349 * * *$ & $\begin{array}{c}-1.719 * * * * \\
(0.272)\end{array}$ \\
\hline $\begin{array}{l}\text { Emergency } \\
\text { Relief/Land }\end{array}$ & 2 & $\mathrm{H}_{0}: \mathrm{r}=0 \mathrm{H}_{1}: \mathrm{r}>=1$ & $18.084 * *$ & $12.295^{* *}$ & $\begin{array}{c}-2.607 * * * \\
(0.624)\end{array}$ \\
\hline Judgments/Land & 1 & $\mathrm{H}_{0}: \mathrm{r}=0 \mathrm{H}_{1}: \mathrm{r}>=1$ & $32.489 * * *$ & $31.948 * * *$ & $\begin{array}{c}-2.586^{* * * *} \\
(0.251)\end{array}$ \\
\hline
\end{tabular}

Notes: The lag order was determined using the AIC criteria. This statistic was minimized at a lag length of 4 for each variable. $* * *$ denotes significance at the 0.01 level.

Source: See text.

Table 6: Granter Causality Test Results

\begin{tabular}{|c|c|c|}
\hline Null Hypothesis & Lag Length & F-statistic \\
\hline $\begin{array}{l}\text { Education Appropriations do not cause Land } \\
\text { Appropriations }\end{array}$ & 2 & $4.27 * *$ \\
\hline $\begin{array}{l}\text { Land Appropriations do not cause Education } \\
\text { Appropriations }\end{array}$ & 2 & 0.01 \\
\hline $\begin{array}{l}\text { Emergency Relief funding does not cause } \\
\text { Land Appropriations }\end{array}$ & 2 & $2.61 *$ \\
\hline $\begin{array}{l}\text { Land Appropriations do not cause } \\
\text { Emergency Relief funding }\end{array}$ & 2 & 0.83 \\
\hline $\begin{array}{l}\text { Judgment Funds do not cause Land Funding } \\
\text { Land Funding does not cause Judgment } \\
\text { Funds }\end{array}$ & $\begin{array}{l}2 \\
2\end{array}$ & $\begin{array}{l}9.84 * * * \\
2.54 *\end{array}$ \\
\hline
\end{tabular}




\section{NOTES}

